\title{
Chlorella vulgaris LOGISTIC GROWTH KINETICS MODEL IN HIGH CONCENTRATIONS OF AQUEOUS AMMONIA
}

\author{
Azlin Suhaida Azmi ${ }^{1}$, Nurain Atikah Che Aziz ${ }^{1}$, Noor Illi Mohamad \\ Puad $^{1 *}$, Amanatuzzakiah Abdul Halim ${ }^{1}$, Faridah Yusof ${ }^{1}$ \\ AND SUZANA YUSUP ${ }^{2}$ \\ ${ }^{I}$ Department of Biotechnology Engineering, Kulliyyah of Engineering, \\ International Islamic University Malaysia, \\ PO Box 10, 50728 Kuala Lumpur, Malaysia. \\ ${ }^{2}$ Department of Chemical Engineering, Universiti Teknologi PETRONAS, \\ Seri Iskandar, 31750 Tronoh, Perak, Malaysia. \\ "Corresponding author: illi@iium.edu.my \\ (Received: $14^{\text {th }}$ Feb 2018; Accepted: $8^{\text {th }}$ Aug 2018; Published on-line: $1^{\text {st }}$ Dec 2018) \\ https://doi.org/10.31436/iiumej.v19.i2.893
}

\begin{abstract}
The ability of microalgae to utilize $\mathrm{CO}_{2}$ during photosynthesis and grow rapidly shows their potential in $\mathrm{CO}_{2}$ bio-fixation to capture and store the gas. However, $\mathrm{CO}_{2}$ capture by this biological approach is very slow compared to chemical reactionbased processes such as absorption using amine or aqueous ammonia. Integration between chemical (aqueous ammonia) and biological (microalgae) aspects might enhance the capturing process and at the same time the microalgae can assimilate $\mathrm{CO}_{2}$ for beneficial bioproduct formation. Thus, it is important to assess the growth of the microalgae in various concentrations of ammonia with $\mathrm{CO}_{2}$ supply. Hence, the main objective of this study is to investigate Chlorella vulgaris growth and its kinetics in aqueous ammonia. To achieve that, $C$. vulgaris was cultivated in various concentrations of aqueous ammonia between 0 to $1920 \mathrm{mg} / \mathrm{L}$ at room temperature $\left(\right.$ i.e. $27{ }^{\circ} \mathrm{C}$ ) and supplied with $15 \%(\mathrm{v} / \mathrm{v})$ of $\mathrm{CO}_{2}$ under illumination of 3500 lux of white fluorescent light. Result shows that the maximum growth capacity $\left(X_{\max }\right)$ of $C$. vulgaris is deteriorating from $1.820 \mathrm{Au}$ to $0.245 \mathrm{Au}$ as the concentration of aqueous ammonia increased. However, no significant change in maximum specific growth rate $\left(\mu_{\max }\right)$ was observed. The growth data was then fitted into the logistic growth model. The model coefficient of determination $\left(R^{2}\right)$ is decreasing, which suggests modification of the model is required.
\end{abstract}

ABSTRAK: Keupayaan alga-mikro untuk menggunakan $\mathrm{CO}_{2}$ semasa proses fotosintesis dan pembiakannya yang pesat menunjukkan potensi dalam penggunaan dan penyimpanan gas ketetapan-biologi. Walau bagaimanapun, penggunaan $\mathrm{CO}_{2}$ melalui cara ini adalah sangat perlahan berbanding proses tindak balas kimia melalui penyerapan amina ataupun cecair ammonia. Percampuran antara tindak balas kimia (cecair ammonia) dan tindak balas biologi, memungkinkan penambahan proses percampuran dan pada masa sama alga-mikro akan menyerap $\mathrm{CO}_{2}$ bagi kepentingan pembentukan hasil biologi. Dengan itu, adalah sangat penting untuk mengawasi pertumbuhan algamikro dalam pelbagai ketumpatan ammonia bersama kandungan $\mathrm{CO}_{2}$. Oleh itu, objektif utama penyelidikan ini adalah untuk menyiasat pertumbuhan Chlorella vulgaris dan proses kinetik dalam cecair ammonia. Bagi memperoleh hasil tersebut, C. vulgaris telah dikulturkan pada ketumpatan cecair berbeza antara $0 \mathrm{ke} 1920 \mathrm{mg} / \mathrm{L}$ pada suhu bilik (iaitu $27^{\circ} \mathrm{C}$ ) dan dibekalkan dengan $15 \%$ (v/v) $\mathrm{CO}_{2}$ di bawah cahaya putih flurosen 3500 lux. 
Keputusan menunjukkan kapasiti pertumbuhan terbanyak $\left(X_{\max }\right)$ C. vulgaris telah berkurang daripada $1.820 \mathrm{Au}$ kepada $0.245 \mathrm{Au}$ apabila ketumpatan cecair ammonia dikurangkan. Walau bagaimanapun, tiada perubahan ketara pada kadar pertumbuhan $\left(\mu_{\max }\right)$ dapat dilihat. Data kadar pertumbuhan kemudiannya dikemas kini pada model pertumbuhan logistik. Model pekali penentu $\left(R^{2}\right)$ telah direndahkan di mana cadangan untuk mengubah model adalah diperlukan.

KEYWORDS: aqueous ammonia; Chlorella vulgaris; growth kinetics; logistic growth model

\section{INTRODUCTION}

Climate change and global warming issues related to excessive emission of $\mathrm{CO}_{2}$ have been deliberatively discussed over years. To address this problem, Malaysia has participated and pledged to reduce $40 \%$ of $\mathrm{CO}_{2}$ emission intensity by 2020 and re-pledged for $45 \%$ of $\mathrm{CO}_{2}$ reduction by year 2030 [1,2]. To achieve the goal, $\mathrm{CO}_{2}$ mitigation is part of the crucial areas identified by The Paris Agreement [1]. Microalgae and cyanobacteria have potential in mitigating $\mathrm{CO}_{2}$ levels in the atmosphere as well as capturing directly from industrial plant flue gas [3-5]. The growth of photosynthetic microalgae is directly related to the rate of $\mathrm{CO}_{2}$ fixation from the atmosphere. Their ability to grow rapidly and undergo photosynthesis makes them strong candidates for use in mitigating $\mathrm{CO}_{2}$ levels [6]. However, the removal rate is still slower and the fixation capacity is lower compared to the chemical solvent absorption process using amine or aqueous ammonia $[7,8]$.

Integrating chemical and biological systems to enhance the removal while simultaneously fixing or sequestrating $\mathrm{CO}_{2}$ for its bioproducts, such as biofuel $[9,10]$, animal feed, or stable isotopes biochemical compound [11] derived from the microalgae, seems appealing. Previous studies show that Chlorella vulgaris a green microalga, was able to grow in wastewater containing a high level of ammonia $[12,13]$. The growth varied with the ammonia concentration at the respective process conditions, which is mostly no aeration or supply of $\mathrm{CO}_{2}$, and the growth was limited by the toxicity of the free ammonia present in the culture. Thus, it is important to assess and understand the growth of $C$. vulgaris in the presence of aqueous ammonia and model the growth.

Generally, like any other microorganisms, there are six phases of $C$. vulgaris growth in a batch culture which are lag, acceleration, growth or exponential, decline, stationary, and death phases (Fig. 1). A general growth model is represented by the exponential growth model of Eq. (1) [14]. This mathematical model equation, when plotted, will produce a J-shape curve where the exponential growth is represented by $\mu_{\max }$, whereas, the typical growth curve shown in Fig. 1, has an S-shape (lag phase to stationary phase). The S-shape growth can be better represented by the logistic growth model of Eq. (2) which was originally proposed by Verhulst in the eighteenth century [15]. The model provides carrying capacity $\left(X_{\max }\right)$ as a moderating force in the growth rate [15] which is influenced by substrate depletion as well as toxic compounds in the environment [16]. The integral form of Eq. (2) is shown by Eq. (3).

$$
\begin{aligned}
& \frac{d X}{d t}=\mu_{\max } X \\
& \frac{d X}{d t}=\mu_{\max }\left(\frac{X_{\max }-X}{X_{\max }}\right) X
\end{aligned}
$$




$$
X(t)=\frac{X_{\max }}{1+\left(\frac{X_{\max }}{X_{o}}+1\right) e^{-\mu_{\max } t}}
$$

where $\mu_{\max }, t, X_{\max }, X_{o}$ and $X$ represent the specific growth rate, time, maximum biomass concentration, initial biomass concentration and actual biomass concentration, respectively. The objective of this study is to assess $C$. vulgaris growth kinetics for its ability to grow in various concentrations of aqueous ammonia with periodically aerated $\mathrm{CO}_{2}$ gas during the cultivation and model the growth based on the logistic growth equation.

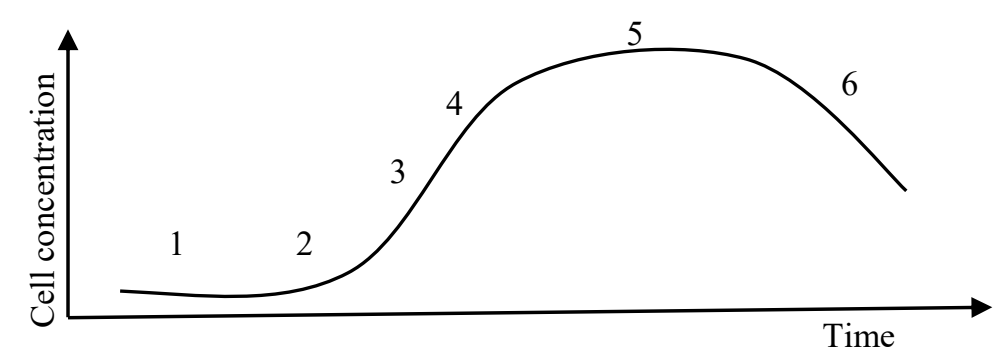

Fig. 1: Growth curve of microalgae culture in batch with phases;

(1) lag, (2) acceleration, (3) growth, (4) deceleration, (5) stationary, and (6) death.

\section{MATERIALS AND METHODS}

\subsection{Microalgae Cultivation}

Stock culture of $C$. vulgaris was purchased from the Institute of Ocean and Earth Sciences, University Malaya and was kept aseptically in a Bold Basal Medium (BBM). A $250 \mathrm{~mL}$ of culture solution was prepared in triplicates which contained $10 \%(\mathrm{v} / \mathrm{v})$ of $C$. vulgaris in BBM medium with the addition of aqueous ammonia at different concentrations. Eight experimental runs were conducted at various aqueous ammonia concentrations i.e. $0 \mathrm{mg} / \mathrm{L}, 30 \mathrm{mg} / \mathrm{L}, 60 \mathrm{mg} / \mathrm{L}, 120 \mathrm{mg} / \mathrm{L}, 240 \mathrm{mg} / \mathrm{L}, 480 \mathrm{mg} / \mathrm{L}, 960 \mathrm{mg} / \mathrm{L}$ and $1920 \mathrm{mg} / \mathrm{L}$. The culture was grown under illumination of 3500 lux from a white fluorescent lamp for 6 days with continuous $(24 \mathrm{~h})$ supply of filtered air at $0.5 \mathrm{Lpm}$. Pure $\mathrm{CO}_{2}$ mixed with filtered air was supplied at a concentration of $15 \%(\mathrm{v} / \mathrm{v})$ every day for 30 minutes continuously. The control of this experiment was conducted without aqueous ammonia $(0 \mathrm{mg} / \mathrm{L})$ with continuous supply of filtered air without extra $\mathrm{CO}_{2}$ (i.e. culture acquired $\mathrm{CO}_{2}$ from the air only). All experimental runs were conducted at room temperature $\left(27^{\circ} \mathrm{C}\right)$ in triplicate. Each flask was fitted with two silicon tubes (one for gas inlet and the other for gas outlet) and the culture was aerated for 24 hours with filtered air generated by air pump through a silicon tube. The sampling for each flask was carried out on a daily basis to measure $C$. vulgaris growth and the $\mathrm{pH}$ of the medium.

\subsection{Determination of Growth Kinetic}

Growth observation was based on the optical density (OD). The absorbance of $C$. vulgaris was determined by measuring the optical density of a $3 \mathrm{~mL}$ sample at a wavelength of $660 \mathrm{~nm}$ for every 24 hours using a UV-vis spectrophotometer. The data was then fitted nonlinearly using a nonlinear regression software, CurveExpert Professional software, version 2.4.0. The logistic equation model (Eq. 3) was selected to fit the data. Eq. (4) was used to calculate $\mu_{\max }$ and compared it to $\mu_{\max }$ obtained from the logistic growth model of Eq. (3). Doubling time was calculated based on Eq. (5). 


$$
\begin{aligned}
& \mu_{\text {max }}=\ln \left(\frac{x_{n-1}}{x_{n}}\right) /\left(\frac{t_{n-1}}{t_{n}}\right) \\
& t_{d}=\frac{\ln 2}{\mu_{\max }}
\end{aligned}
$$

\section{RESULTS AND DISCUSSION}

\subsection{Growth of $C$. vulgaris in BBM with air supply}

Growth of $C$. vulgaris in BBM with the continuous air supply was studied before introducing aqueous ammonia and $\mathrm{CO}_{2}$. This is to observe the typical growth kinetic and the stationary phase of $C$. vulgaris as illustrated in Fig. 1. Since the stationary phase of growth was observed as it entered the $4^{\text {th }}$ day of cultivation, a subsequent cultivation run was conducted up to the $6^{\text {th }}$ day after inoculation.

Figure 2(a) shows growth data in absorbance unit of optical density at $660 \mathrm{~nm}$, while Fig. 2(b) is the same growth data in the form of natural-logarithms. Generally, the growth curve consists of six phases that have been discussed earlier. The same phases were also observed in $C$. vulgaris growth except for the death phase. This is due to a longer stationary phase (more than 12 days) of $C$. vulgaris which some have recorded being up to one month depending on the growth conditions [17,18]. In this study, the growth was monitored only for the duration of up to 12 days, thus the death phase was not perceived.

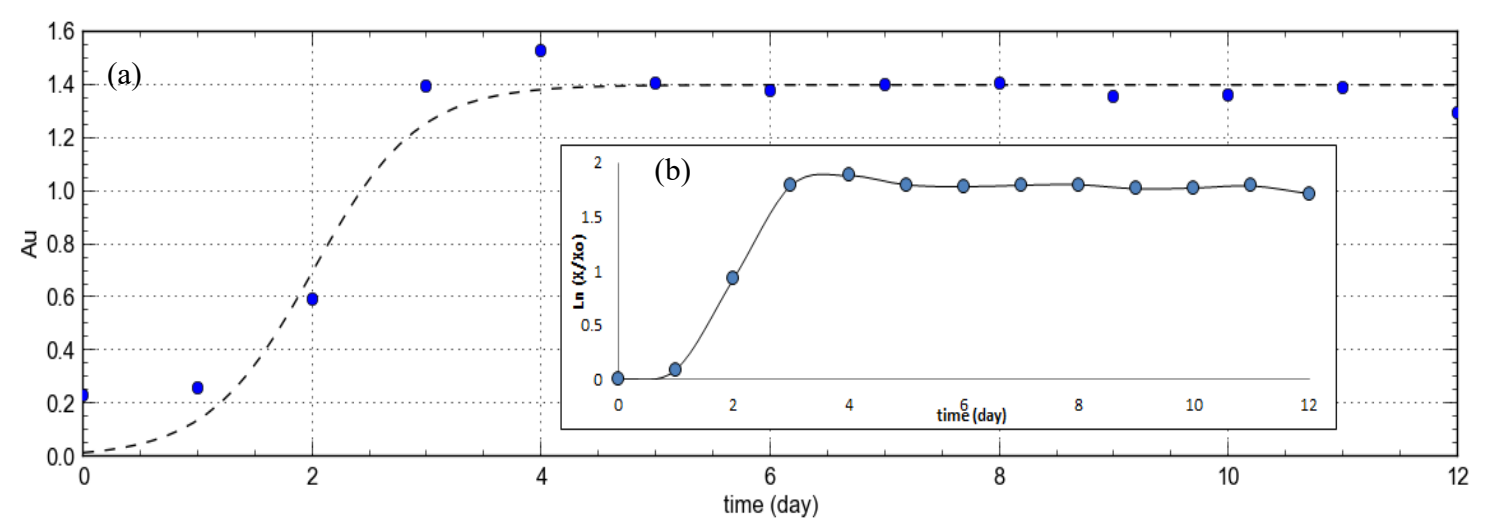

Fig. 2: The growth profile of C. vulgaris in BBM medium with (a) fitted model in dash line for circle symbol data and (b) growth curve in logarithms.

According to Doran [14], lag phase is best observed and confirmed in a logarithmic plotted curve as shown in Fig. 2(b). The figure shows that the cells required one day of adaptation (lag phase) to the new environment before entering the exponential (growth) phase. The exponential phase was started from day 2 to day 4 before entering the stationary phase (day 4 onwards). The maximum specific growth rate $\left(\mu_{\max }\right)$ and doubling time $\left(t_{d}\right)$ of the microalgae were 0.847 day $^{-1}\left(0.036 \mathrm{~h}^{-1}\right)$ and 0.818 day $\left(0.034 \mathrm{~h}^{-1}\right)$, respectively, as shown in Table 1 . The $\mu_{\max }$ obtained in this research is much lower compared to Lehana [19] (i.e. $0.24 \mathrm{~h}^{-1}$ ) in a continuous culture but higher than Converti et al. [20] (i.e. 0.14 day $^{-1}$ ) grown in batch culture at about the same culture conditions as the current study. However, those studies used larger culture volumes of $3 \mathrm{~L}$ with $8 \%$ of $\mathrm{CO}_{2}$ in air and $2 \mathrm{~L}$ with air only supplied to the culture, respectively whereas the current study is in a $250 \mathrm{~mL}$ culture medium with filtered air. Microalgae culture grown with aeration of 
extra $\mathrm{CO}_{2}$ as in Lehana [19] in continuous culture, has been shown to improve its growth rate compared to the culture grown with air only [4]. However, the lower maximum specific growth rate by Converti et al. [20] is due to the size of the culture, which in our study the air was supplied at flowrate of $2 \mathrm{vvm}(0.5 \mathrm{Lpm})$. The growth of the current study was then modelled using the logistic growth equation with a coefficient of determination $\left(R^{2}\right)$ of 0.95 . However, the model predicted a very low rate of initial growth compared to the experimental data and this affected the values of other parameters shown in Table 1.

Table 1: Comparison of parameters obtained from logistic growth model fitting (Fig. 2(a)) and experimental data (Fig. 2(b)) for growth in BBM only.

\begin{tabular}{lcc}
\hline Parameter & $\begin{array}{c}\text { Value } \\
\text { predicted by } \\
\text { model }\end{array}$ & $\begin{array}{c}\text { Value from } \\
\text { experimental } \\
\text { data }\end{array}$ \\
\cline { 2 - 3 } $\boldsymbol{X}_{\boldsymbol{o}}(\mathbf{A u})$ & 0.017 & 0.233 \\
$\boldsymbol{X}_{\max }(\mathbf{A u})$ & 1.399 & 1.524 \\
$\boldsymbol{\mu}_{\max }\left(\mathbf{d a y}^{-1}\right)$ & 2.190 & 0.847 \\
$\boldsymbol{t}_{\boldsymbol{d}}(\mathbf{d a y})$ & 0.317 & 0.818 \\
$\boldsymbol{R}^{2}$ & 0.95 & 1 \\
\hline
\end{tabular}

\subsection{Growth Kinetics of $C$. vulgaris at Different Concentrations of Ammonia}

This experiment was conducted to understand how C. vulgaris responded to different concentrations of ammonia with the aeration rate of $0.5 \mathrm{Lpm}$ for $15 \%(\mathrm{v} / \mathrm{v}) \mathrm{CO}_{2}$ in filtered air for 30 minutes every day under the illumination of 3500 lux. Since C. vulgaris growth reached the stationary phase in the beginning of day 5 (Fig. 2), subsequent observation of the microalgae growth was only recorded until day six in variation of ammonia concentrations (Fig. 3). The control run $\left(0 \mathrm{mg} / \mathrm{L}\right.$ ammonia with $\left.15 \% \mathrm{CO}_{2}\right)$ achieved the highest growth capacity $\left(X_{\max }\right)$ of $1.8 \mathrm{Au}$ (Absorption unit) at $\mathrm{OD}_{660}$ (Fig. 3(a)). The growth was higher compared to the growth supplied with air only (Fig. 2). This shows that, even though $15 \%(\mathrm{v} / \mathrm{v})$ of $\mathrm{CO}_{2}$ was supplied for only 30 minutes every day, it had a positive influence on $C$. vulgaris growth (note that the initial cell density was maintained at around $0.2 \mathrm{Au}$ for all runs). Many have reported how $\mathrm{CO}_{2}$ influences the growth of photosynthetic microorganisms such as $C$. vulgaris $[4,21,22]$ under illumination of light. The surrounding air, which contains only $0.03-0.06 \% \mathrm{CO}_{2}$, had limited $C$. vulgaris photosynthetic activity and slowed down its cell growth [23].

However, when aqueous ammonia was introduced in the culture at different concentrations, it is apparent that $C$. vulgaris growth was significantly influenced by the addition of aqueous ammonia. This is reflected by the decrease in the carrying capacity $\left(X_{\max }\right)$ values from both the model and the experimental data (Table 2). Nitrogen is a crucial nutrient for microalgae growth, which is assimilated in the form of nitrate $\left(\mathrm{NO}_{3}{ }^{-}\right)$ or ammoniacal nitrogen $\left(\mathrm{NH}_{4}{ }^{+} / \mathrm{NH}_{3}\right)$. However, higher ammonia concentration can be toxic to the microalgae growth. This is especially depicted by Fig. $3(\mathrm{~g})$ and $(\mathrm{h})$ where ammonia concentration of $960 \mathrm{mg} / \mathrm{L}$ and above showed that the growth of the microalgae was nearly inhibited. However, this is not the case for $\mu_{\max }$. Generally, $\mu_{\max }$ (Table 2) obtained from experimental data (calculated based on Eq. (4)) are about the same, even though concentration of ammonia increased in a double amount of the previous concentration. The same was also observed by Tam and Wong [24]. A few papers suggested that $\mu_{\max }$ is an important parameter in modelling microalgae or microbial population in batch production that is influenced by environmental factors [15,25]. In our 
case, no significant change in $\mu_{\max }$ was observed at various concentrations of ammonia. However, the $X_{\max }$ should also be considered as it is directly influenced by the environmental factor such as $\mathrm{pH}$, temperature, nutrient, and others, which in this case is the ammonia toxicity.

(a)

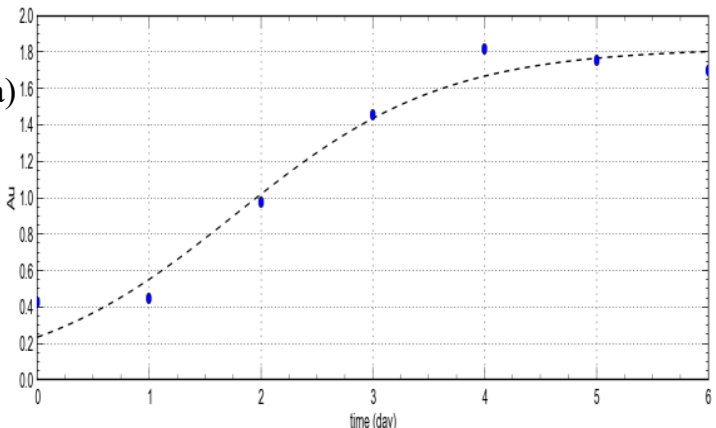

(c)

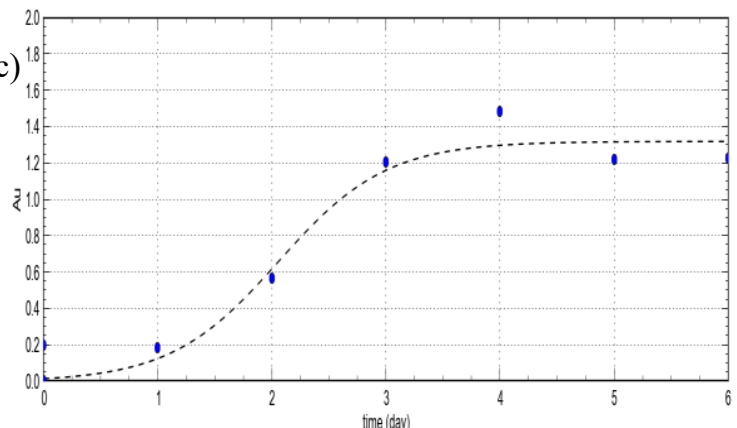

(e)

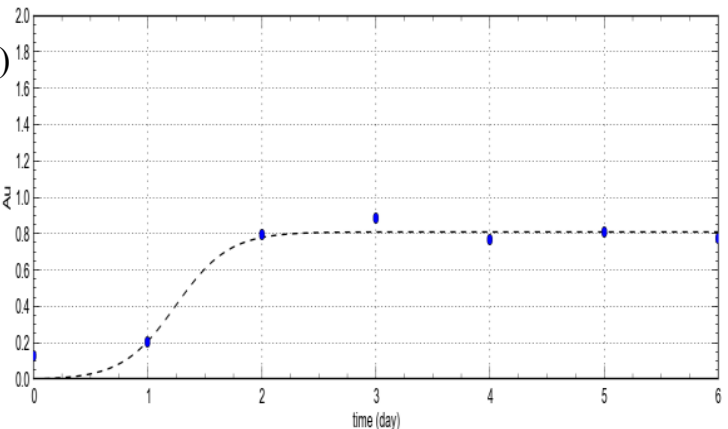

(g)

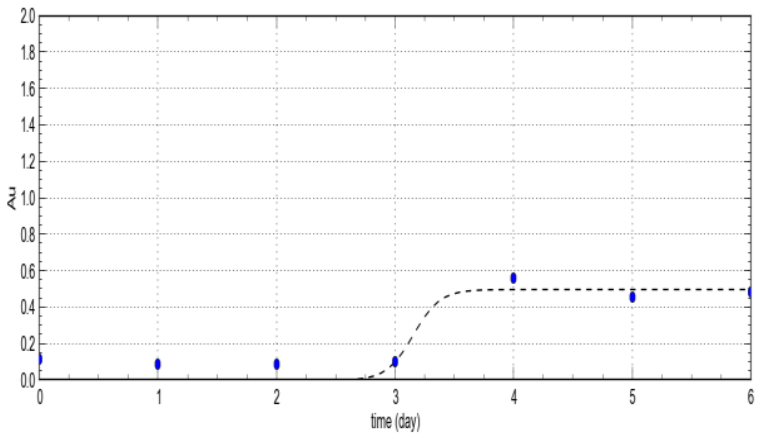

(b)

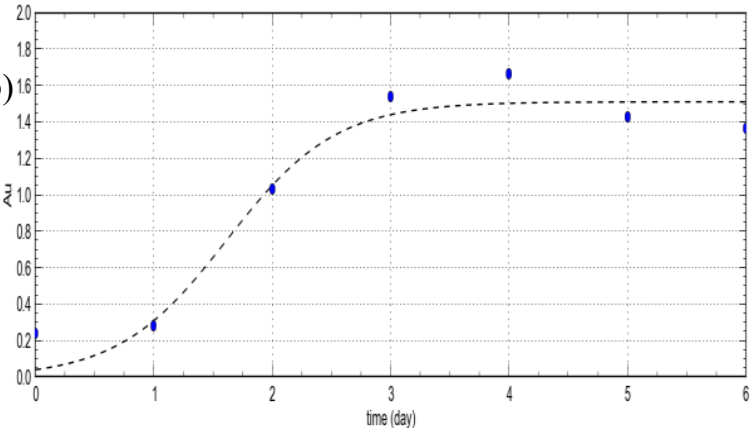

(d)
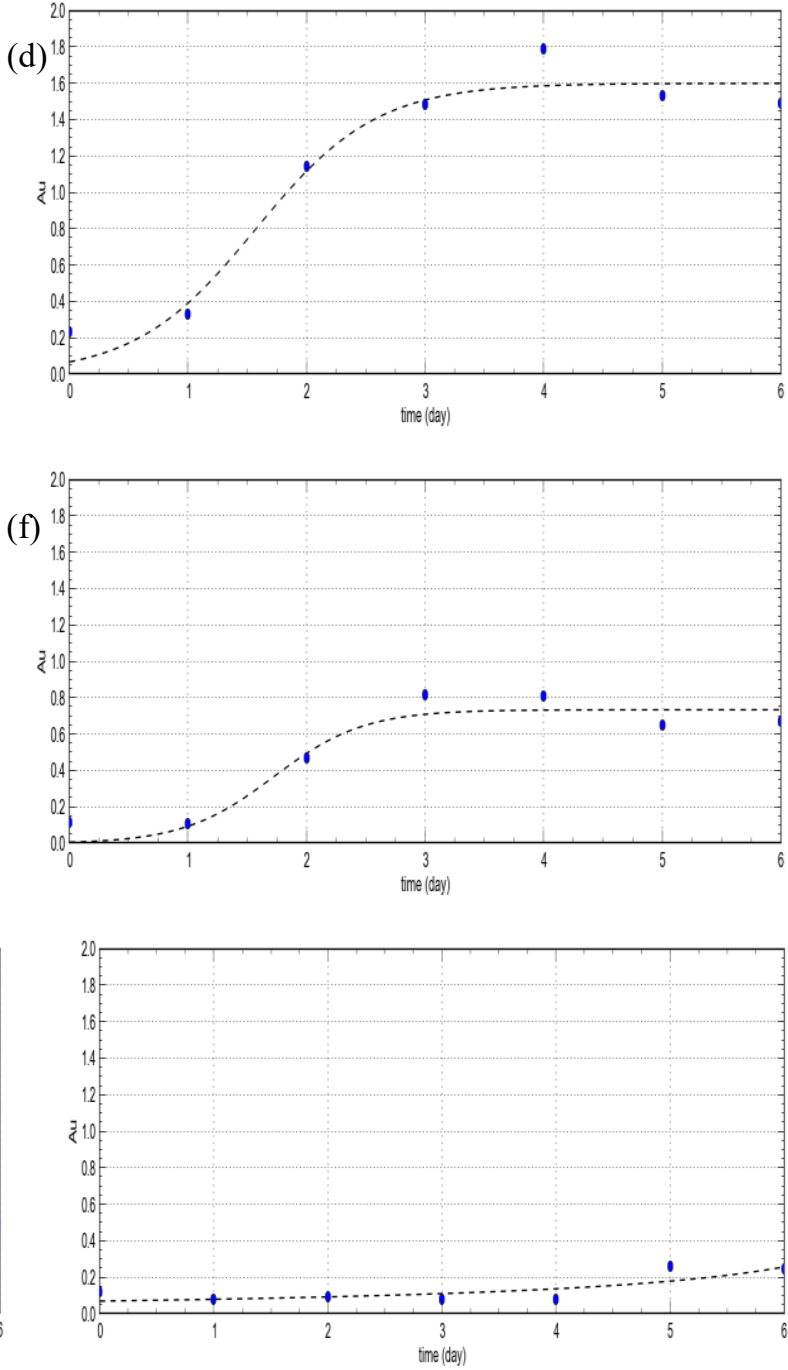

Fig. 3: Growth of $C$. vulgaris fitted in modified logistic equation at (a) $0 \mathrm{mg} / \mathrm{L}$, (b) $30 \mathrm{mg} / \mathrm{L}$, (c) $60 \mathrm{mg} / \mathrm{L}$, (d) $120 \mathrm{mg} / \mathrm{L}$, (e) $240 \mathrm{mg} / \mathrm{L}$, (f) $480 \mathrm{mg} / \mathrm{L}$, (g) $960 \mathrm{mg} / \mathrm{L}$ and (h) $1920 \mathrm{mg} / \mathrm{L}$. 
C. vulgaris growth is well fitted into the logistic growth kinetic model as depicted in Fig. 2 with $R^{2}$ between 0.88 to 1 (Table 2) except for the ammonia at the concentration of $1920 \mathrm{mg} / \mathrm{L}$. The equation perfectly modelled the growth without ammonia with $\mathrm{CO}_{2}$ supply. However, as the ammonia concentration increased, the $R^{2}$ was reduced and overestimated some of the parameters. This suggests that a model modification or application of another growth model that takes ammonia concentration and toxicity into account might be needed.

Table 2: Comparison of parameters obtained from logistic growth model and experimental data for variation of ammonia concentration.

\begin{tabular}{|c|c|c|c|c|c|c|c|}
\hline \multirow{2}{*}{$\begin{array}{l}\mathrm{NH}_{3} \\
\text { concentration } \\
\left(\mathbf{m g} \cdot \mathbf{L}^{-1}\right)\end{array}$} & \multicolumn{4}{|c|}{ Parameters predicted by model } & \multicolumn{3}{|c|}{ Parameter from experimental data } \\
\hline & $\mathbf{R}^{2}$ & $\begin{array}{l}X_{\max } \\
\text { (Au) }\end{array}$ & $\begin{array}{c}X_{o} \\
(\mathbf{A u})\end{array}$ & $\begin{array}{c}\mu_{\max } \\
\left(\text { day }^{-1}\right)\end{array}$ & $\begin{array}{l}X_{\max } \\
(\mathrm{Au}) \\
\end{array}$ & $\begin{array}{c}X_{o} \\
(\mathrm{Au})\end{array}$ & $\begin{array}{c}\mu_{\max } \\
\left(\mathrm{day}^{-1}\right)\end{array}$ \\
\hline 0 & 1.00 & 1.8200 & 0.4300 & 0.7787 & 1.8200 & 0.43 & 0.7787 \\
\hline 30 & 0.95 & 1.5135 & 0.0433 & 2.1813 & 1.6660 & 0.239 & 1.2909 \\
\hline 60 & 0.94 & 1.3217 & 0.0169 & 2.1137 & 1.4840 & 0.201 & 1.1075 \\
\hline 120 & 0.96 & 1.6024 & 0.0704 & 1.9631 & 1.7890 & 0.231 & 1.2410 \\
\hline 240 & 0.96 & 0.8128 & 0.0039 & 4.2902 & 0.8870 & 0.127 & 1.3481 \\
\hline 480 & 0.92 & 0.7367 & 0.0080 & 2.6265 & 0.8170 & 0.115 & 1.4614 \\
\hline 960 & 0.88 & 0.4997 & 0.0000 & 8.8764 & 0.5620 & 0.111 & 1.6968 \\
\hline 1920 & 0.67 & 0.0001 & 0.0728 & 0.0001 & 0.2450 & 0.12 & 1.1670 \\
\hline
\end{tabular}

The $\mathrm{pH}$ of the medium was originally adjusted to 6.8 with $1 \mathrm{~N} \mathrm{KOH}$ before inoculation of the green microalgae. There were no significant changes in $\mathrm{pH}$ when ammonia was added in the medium until the ammonia concentration increased to 240 $\mathrm{mg} / \mathrm{L}$ and above, the $\mathrm{pH}$ changed to 9.97 and higher as shown in Fig. 4. However when $\mathrm{CO}_{2}$ was introduced in the culture medium, the $\mathrm{pH}$ reduced before it increased back as cell growth was observed. The increase of $\mathrm{pH}$ level as growth increased was also reported by others [26-28]. The growth of $C$. vulgaris in cultures containing ammonia is usually accompanied with a change in $\mathrm{pH}$ as the medium becomes acidic in the lag phase and then changes to alkaline when the cells are in the log or stationary phase.

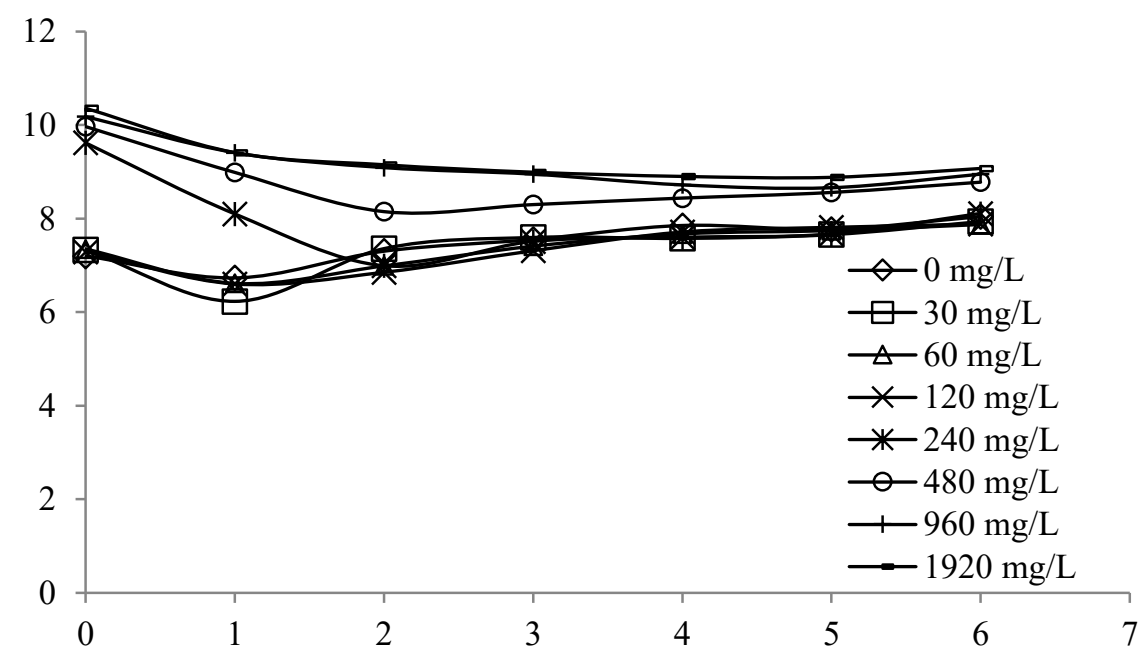

Fig. 4: Medium $\mathrm{pH}$ of C. vulgaris culture at different ammonia concentrations . 


\section{CONCLUSION}

Growth of $C$. vulgaris in BBM with continuous air pumped into the culture was observed for a duration of 12 days to study the growth characteristic of $C$. vulgaris before introducing $\mathrm{CO}_{2}$ and ammonia. The growth profile exhibits all phases (except death phase), with a significant extended stationary phase starting from day 4 onwards. Due to that, subsequent experimental runs were conducted for only six days.

Subsequently, eight runs were conducted at various concentrations of ammonia from 0 $\mathrm{mg} / \mathrm{L}$ to $1920 \mathrm{mg} / \mathrm{L}$ with $15 \%(\mathrm{v} / \mathrm{v})$ of $\mathrm{CO}_{2}$ aerated at the volumetric flow rate of $0.5 \mathrm{Lpm}$ under illumination at $3500 \mathrm{Lux}\left(12\right.$ light:12 dark) at $27^{\circ} \mathrm{C}$. The highest growth was observed from the culture with $0 \mathrm{mg} / \mathrm{L}$ of aqueous ammonia aerated with $\mathrm{CO}_{2} . C$. vulgaris growth capacity however declined with the increase of ammonia concentration. The data were also not well fitted into the logistic growth model as the concentration increased, suggesting modification of the model is required. The $\mathrm{pH}$ of the culture medium is influenced by growth of the cell in the presence of ammonia.

\section{ACKNOWLEDGEMENT}

The authors are grateful to the management of International Islamic University Malaysia for a research fund (RIGS16-089-0253) for this work.

\section{REFERENCES}

[1] Begum RA. (2017) Tackling Climate Change and Malaysia's Emission Reduction Target, In Scientific Malaysian. [http://magazine.scientificmalaysian.com/issue-13-2017/tacklingclimate-change-malaysias-emission-reduction-target/]

[2] Lokman T. (2017) PM: Malaysia on course to reduce carbon emissions by 40 pet by 2020 , In New Straits Times. [https://www.nst.com.my/news/nation/2017/12/310231/pm-malaysiacourse-reduce-carbon-emissions-40-pct-2020]

[3] Benemann J, Pedroni PM, Davison J, Beckert H, Bergman P. (2003) Technology roadmap for biofixation of $\mathrm{CO}_{2}$ and greenhouse gas abatement with microalgae, In Second National Conference on Carbon Sequestration. [https://www.netl.doe.gov/publications/proceedings/03/carbon-seq/PDFs/017.pdf]

[4] Azmi AS, Amid A, Puad NIM, Jamal P. (2017) The effect of $\mathrm{CO}_{2}$ concentrations and the injection strategy on Synechococcus sp. PCC7002 culture, Asia Pacific of Molecular Biology and Biotechnology, 25:56-60.

[5] Fan LH, Zhang YT, Cheng LH, Zhang L, Tang DS, Chen HL. (2007) Optimization of carbon dioxide fixation by Chlorella vulgaris cultivated in a membrane-photobioreactor, Chemical Engineering \& Technology, 30:1094-1099.

[6] Zhang X. (2015) Microalgae removal of $\mathrm{CO}_{2}$ from flue gas. IEA Clean Coal Centre, UK.

[7] Clément-Larosière B, Lopes F, Gonçalves A, Taidi B, Benedetti M, Minier M, Pareau D. (2014) Carbon dioxide biofixation by Chlorella vulgaris at different $\mathrm{CO}_{2}$ concentrations and light intensities. Engineering in Life Sciences 14:509-519.

[8] Yeh AC, Bai H. (1999) Comparison of ammonia and monoethanolamine solvents to reduce $\mathrm{CO}_{2}$ greenhouse gas emissions. Science of the Total Environment, 228:121-133.

[9] Blinová L, Bartošová A, Gerulová K. (2015) Cultivation of Microalgae (Chlorella vulgaris) for Biodiesel Production. Research Papers Faculty of Materials Science and Technology Slovak University of Technology, 23:87-95.

[10] Ahmad A, Yasin NM, Derek C, Lim J. (2011) Microalgae as a sustainable energy source for biodiesel production: A review. Renewable and Sustainable Energy Reviews, 15:584-593.

[11] Spolaore P, Joannis-Cassan C, Duran E, Isambert A. (2006) Commercial applications of microalgae. J. Bioscience and Bioengineering, 101:87-96. 
[12] He P, Mao B, Shen C, Shao L, Lee D, Chang J. (2013) Cultivation of Chlorella vulgaris on wastewater containing high levels of ammonia for biodiesel production., Bioresource Technology, 129:177-181.

[13] Kim J, Lingaraju BP, Rheaume R, Lee J-Y, Siddiqui KF. (2010) Removal of ammonia from aastewater effluent by Chlorella Vulgaris. Tsinghua Science \& Technology, 15:391-396.

[14] Doran PM. (1995) Homogeneous Reactions. In Bioprocess Engineering Principles, Academic press, London, Great Britain; pp257-296.

[15] Peleg M, Corradini MG, Normand MD. (2007) The logistic (Verhulst) model for sigmoid microbial growth curves revisited. Food Research International, 40:808-818.

[16] Escalante FM, Reyna-Angeles KA, Villafaña-Rojas J, Aguilar-Garnica E. (2017) Kinetic model selection to describe the growth curve of Arthrospira (Spirulina) maxima in autotrophic cultures. J. Chemical Technology and Biotechnology, 92:1406-1414.

[17] Blair MF, Kokabian B, Gude VG. (2014) Light and growth medium effect on Chlorella vulgaris biomass production. J. Environmental Chemical Engineering, 2:665-674.

[18] Sibi G. (2015) Low cost carbon and nitrogen sources for higher microalgal biomass and lipid production using agricultural wastes. J. Environmental Science and Technology, 8(3):113121.

[19] Lehana M. (1990) Kinetic analysis of the growth of Chlorella vulgaris. Biotechnology and Bioengineering, 36:198-206.

[20] Converti A, Casazza AA, Ortiz EY, Perego P, Del Borghi M. (2009) Effect of temperature and nitrogen concentration on the growth and lipid content of Nannochloropsis oculata and Chlorella vulgaris for biodiesel production. Chemical Engineering and Processing: Process Intensification, 48:1146-1151.

[21] Singh S, Singh P. (2014) Effect of $\mathrm{CO}_{2}$ concentration on algal growth: A review. Renewable and Sustainable Energy Reviews, 38:172-179.

[22] Anjos M, Fernandes BD, Vicente AA, Teixeira JA, Dragone, G. (2013) Optimization of $\mathrm{CO}_{2}$ bio-mitigation by Chlorella vulgaris. Bioresource Technology, 139:149-154.

[23] Wang B, Li Y, Wu N, Lan C. (2008) $\mathrm{CO}_{2}$ bio-mitigation using microalgae. Applied Microbiology and Biotechnology, 79:707-718.

[24] Tam NFY, Wong YS. (1996) Effect of ammonia concentrations on growth of Chlorella vulgaris and nitrogen removal from media. Bioresource Technology, 57:45-50.

[25] Dalgaard P, Koutsoumanis K. (2001) Comparison of maximum specific growth rates and lag times estimated from absorbance and viable count data by different mathematical models. J. Microbiological Methods, 43:183-196.

[26] Kim J, Lee J-Y, Keener T. (2009) Growth kinetic study of Chlorella vulgaris. AIChE Annual Meeting, American Institute of Chemical Engineers, Nashville, TN, United States; pp 1-6.

[27] Przytocka-Jusiak M, Duszota M, Matusiak K, Mycielski R. (1984) Intensive culture of Chlorella vulgaris/AA as the second stage of biological purification of nitrogen industry wastewaters. Water Research, 18:1-7.

[28] Santoso A. (2015) Increasing lipid accumulation of Chlorella vulgaris using Spirulina platensis in flat plate reactor for synthesizing biodiesel. Energy Procedia, 65:58-66. 